\title{
PENEMUAN HUKUM OLEH KPPU \\ DALAM PRAKTIK HUKUM PERKARA PERSAINGAN USAHA
}

\author{
Murni \\ Fakultas Hukum Universitas Trunojoyo Madura \\ Kampus Unijoyo, Telang, PO. BOX 2 Kamal - Bangkalan \\ Email: murni_msy@yahoo.co.id
}

\begin{abstract}
Rechtsvinding is the process of law-making by judges or other law enforcement officials in order to apply the common law rules on concrete legal events. KPPU is a quasi-judicial, a competition law enforcement has the authority to receive the report, to prosecution, to examine and decide the case in the field of business competitions. As the judiciary, the KPPU authorized rechtsvinding based on interpretation of the law by using per se illegal approach or rule of reasons.
\end{abstract}

Key words: rechsvinding, business competition, KPPU

\begin{abstract}
Abstrak
Penemuan hukum merupakan proses pembentukan hukum oleh hakim atau aparat penegak hukum lainnya dalam rangka untuk menerapkan peraturan hukum umum pada peristiwa hukum konkret. Komisi Pengawas Persaingan Usaha (KPPU) adalah lembaga quasi peradilan penegak hukum persaingan usaha yang mempunyai kewenangan penerimaan laporan, penuntutan, pemeriksaan dan memutus perkara di bidang persaingan usaha. Sebagai lembaga peradilan, maka KPPU dapat melakukan penemuan hukum berdasarkan interpretasi dengan menggunakan pendekatan per se illegal atau rule of reason.
\end{abstract}

Kata kunci: penemuan hukum, persaingan usaha, KPPU

\section{Latar belakang}

Tatanan di dalam suatu negara yang berdasarkan hukum, mengamanahkan bahwa setiap perkara hukum yang timbul dalam kehidupan bermasyarakat akan diadili dan diputus oleh suatu badan kekuasaan kehakiman. Kewenangan itu ditegaskan dalam ketentuan Pasal 1 ayat (1) Undang-undang Nomor 48 Tahun 2009 tentang Pokok-pokok kekuasaan kehakiman, bahwa "Kekuasaan kehakiman adalah kekuasaan negara yang merdeka untuk menyelenggarakan peradilan guna menegakkan hukum dan keadilan berdasarkan Pancasila dan Undang-undang Dasar 1945, demi terselenggaranya negara Hukum Republik Indonesia”.

Selanjutnya ditetapkan dalam pasal berikut, yaitu Pasal 10 ayat (1), bahwa "Pengadilan dilarang menolak untuk memeriksa, mengadili, memutus suatu perkara yang diajukan dengan dalih hukum tidak ada atau kurang jelas, melainkan wajib untuk 
memeriksa dan mengadilinya". Ketentuan ini menegaskan dianutnya asas larangan menolak perkara (rechsweigering), hal ini memberikan makna bahwa hakim sebagai aparat utama pengadilan dan sebagai pelaksana kekuasaan kehakiman wajib hukumnya bagi hakim untuk menemukan hukumnya dalam suatu perkara meskipun ketentuan hukumnya atau aturan hukum tidak ada atau kurang jelas. Lahirnya asas rechsweigering, dilandasi oleh adanya kenyataan bahwa tidak ada undangundang yang benar-benar lengkap, jelas dan sempurna, sehingga dalam keadaan yang tidak sempurna tersebut hakim tetap harus mampu menemukan hukum atas peristiwa hukum yang terjadi.

Dua ketentuan di atas, jika dikaitkan dengan Pasal 5 ayat (1) dalam undang-undang yang sama menyatakan bahwa "Hakim dan hakim konstitusi wajib menggali, mengikuti dan memahami nilai-nilai hukum dan rasa keadilan yang hidup dalam masyarakat". Pasal tersebut memberi pesan kepada hakim sebagai aparat penegak hukum tidak boleh terpaku semata-mata pada adanya undangundang. Dengan kata lain, "Putusan hakim tidak boleh sekedar memenuhi formalitas hukum atau sekedar memelihara ketertiban. Putusan hakim harus berfungsi mendorong perbaikan dalam masyarakat dan membangun harmonisasi sosial dalam pergaulan. Hanya dengan cara itu, putusan hakim akan benar dan adil". ${ }^{1}$

Kewajiban hakim untuk menggali tersebut juga menunjukkan bahwa negara Indonesia bukanlah suatu negara yang menganut pandangan legisme yang hanya memberi tempat kepada produk perundang-undangan. ${ }^{2}$ Kewajiban ini berarti hakim harus melakukan upaya penemuan hukum. Kasus yang sempat mengemuka mengenai penemuan hukum dalam praktik peradilan, yaitu putusan pengadilan tentang perubahan jenis kelamin seorang pria menjadi wanita, yang dikenal dengan Kasus Vivian. ${ }^{3}$

Penemuan hukum termasuk kegiatan sehari-hari para yuris, dan terjadi pada semua bidang hukum, seperti hukum pidana, hukum perdata, hukum pemerintahan dan hukum pajak. Penemuan hukum merupakan aspek penting dalam ilmu hukum dan praktik hukum. Profesi sebagai ahli hukum pada dasarnya harus membuat keputusan-keputusan hukum, berdasarkan hasil analisanya terhadap faktafakta hukum harus dapat dipilah antara mana yang termasuk fakta hukum dan mana yang bukan sehingga memunculkan suatu masalah hukum.

Permasalahan yang muncul kemudian adalah situasi dimana rumusan pasal dalam undang-undang tersebut belum jelas, belum lengkap atau tidak dapat membantu seorang

1 Sudikno Mertokusumo dan Pitlo, Bab-bab tentang Penemuan Hukum, Citra Aditya Bakti, Bandung, 1993, hlm. 2.

2 Peter Mahmtud Marzuki, Penemuan Hukum, Makalah Seminar Nasional Peran Hakim dalam Penemuan Hukum, Fakultas Hukum Universitas Airlangga, Surabaya, 22 September 2012, hlm.10.

3 Yudha Bakti Adhiwisastra, Penafsiran dan Konstruksi Hukum, Alumni, Bandung, 2000, hlm. 2. 
ahli hukum dalam penyelesaian suatu perkara atau masalah hukum. Dalam situasi seperti ini, seorang ahli hukum tidak dapat begitu saja menolak untuk menyelesaikan perkara tersebut. Artinya, seorang ahli hukum harus bertindak atas inisiatif sendiri untuk menyelesaikan perkara yang bersangkutan. Tindakan seorang ahli hukum dalam situasi semacam itulah yang dimaksudkan dengan pengertian penemuan hukum atau Rechtsvinding. Hakim hanya boleh menolak untuk memeriksa suatu perkara, bilamana undang-undang menentukan lain, misalnya karena alasan kompetensi, adanya hubungan darah dengan pihak-pihak, atau karena adanya alasan bahwa perkara sudah diperiksa dan diputus (nebis in idem). ${ }^{4}$

Upaya penemuan hukum oleh hakim ini menuntut seorang hakim untuk bertindak atas inisiatif sendiri menemukan dan menggali nilai-nilai hukum yang tidak tertulis yang hidup di dalam masyarakat (living law). Untuk itu, hakim tidak hanya berkewajiban melaksanakan bunyi undang-undang, namun dia juga wajib menegakkan keadilan bagi pihak-pihak, sehingga dia harus memikirkan perihal kehidupan yaitu berfikir mengenai tata cara terbaik untuk hidup manusia, yakni thinking about justice seems inescapably to engage us in thinking abaout the best way of live. ${ }^{5}$ Hakim harus terjun ke tengah-tengah masyarakat untuk mengenal, merasakan dan mampu menyelami perasaan hukum dan rasa keadilan yang hidup dalam masyarakat. Menurut asas ius curia novit, hakim dalam menemukan hukum tidak boleh bertentangan dengan hukum yang hidup dalam masyarakat.

Tidak hanya hakim yang dapat melakukan penemuan hukum, aparat penegak hukum selain hakim juga dapat melakukan penemuan hukum. Di era reformasi ini beberapa peradilan khusus dibentuk berada di bawah Peradilan Umum, Peradilan Agama, Peradilan Militer ataupun Peradilan Tata Usaha negara. Untuk itu, pelembagaan semua badan peradilan tersebut secara konstitusional haruslah dilihat dalam konteks keempat lingkungan peradilan yang telah ditentukan oleh Pasal 24 Undangundang Dasar Negara Republik Indonesia 1945 (UUD NRI 1945) tersebut di atas. Di samping itu, pengertian peradilan juga harus diperluas ke dalam makna yang lebih substantif dan luas.

Proses peradilan tidak hanya dilakukan melalui proses di pengadilan (in-court), tetapi dapat pula dilakukan di luar pengadilan (out of court). Karena itu, sejalan dengan perkembangan praktik peradilan di seluruh dunia dewasa ini, semua proses penyelesaian konflik hukum dapat disebut sebagai proses peradilan dalam arti yang luas, ${ }^{6}$ meskipun tidak secara eksplisit sebagai lembaga

4 Bagir Manan, Menjadi Hakim yang Baik, Varia Peradilan, No. 255, Februari 2007, hlm. 12.

5 Michael J Sandel, Justice: Whats The Right Thing To Do?, Farrar, Straus And Giroux, New York, 2004, hlm. 10.

6 Jimly Assiddiqie, Fungsi Campuran KPPU Sebagai Quasi Peradilan, http://www.jimly.com/makalah/ namafile/61/Makalah_KPPU_Koreksian.pdf, diakses 28 April 2009, pikul 09.15 WIB. 
pengadilan. Lembaga-lembaga seperti Komisi Pengawas Persaingan Usaha (KPPU) juga dapat kita lihat dalam konteks penyelesaian masalah-masalah hukum di bidang persaingan usaha yang sehat yang dikembangkan secara luas sejak dibentuknya Undang-undang No.5 Tahun 1999 tentang Larangan Praktik Monopoli dan Persaingan Usaha Tidak Sehat. ${ }^{7}$

Lembaga KPPU dibentuk secara khusus untuk menangani masalah-masalah yang berkenaan dengan perilaku pelaku usaha yang dapat menimbulkan praktik monopoli dan persaingan usaha tidak sehat yang dilarang oleh UU Persaingan Usaha, seperti perilaku pelaku usaha untuk merusak pasar dengan cara melakukan praktik monopoli, oligopoli dan perilaku lain yang dilarang, baik dalam bentuk perjanjian maupun kegiatan. Karakter tugas dan kewenangan KPPU yang hampir menyerupai badan peradilan (Pasal 35 dan 36 UU Persaingan Usaha) inilah, maka keberadaan KPPU disebut sebagai lembaga quasi peradilan. ${ }^{8}$ Menelaah kewenangan yang dimiliki KPPU, apakah dengan demikian KPPU dapat melakukan penemuan hukum sebagaimana yang diamanahkan oleh Undangundang Nomor 48 Tahun 2009? Dan jika demikian, apa metode penemuan hukum yang digunakan oleh KPPU dalam memeriksa, mengadili serta memutus perkara persaingan usaha jika hukum yang mengaturnya tidak jelas atau tidak lengkap?

\section{Pembahasan}

\section{A. Kewenangan KPPU dalam Penemuan Hukum}

Penemuan hukum lazimnya diartikan sebagai proses pembentukan hukum oleh hakim atau petugas-petugas hukum lainnya yang diberi tugas melaksanakan hukum terhadap peristiwa-peristiwa hukum konkrit. ${ }^{9}$ Lazimnya memang penemuan hukum utamanya dilakukan oleh hakim (rechterlijke rechtsvinding) namun juga dimungkinkan dilakukan oleh penegak hukum lainnya, dan dalam lingkungan akademisi seringkali hal itu dilakukan oleh para ilmuwan atau pakar hukum. Penemuan hukum yang dilakukan oleh hakim (rechterlijke rechtsvinding) merupakan salah satu bentuk penemuan hukum dari praktik hukum ofisial ( officiele rechtspraktijk $)^{10}$. Hal ini menunjukkan bahwa penemuan hukum bukan satu-satunya dapat dilakukan oleh hakim dalam empat lingkungan peradilan yang terdapat dalam Pasal 10 Undang-undang Nomor 14 Tahun 1970, tetapi juga dapat dilakukan oleh hakim yang berada dalam lingkungan peradilan khusus. ${ }^{11}$

7 Selanjutnya disebut UU Persaingan Usaha

8 Jimly Assiddiqie, Perkembangan dan Konsolidasi Lembaga Negara Pasca Reformasi, Sinar Grafika, Jakarta, 2010, hlm. 15.

9 Sudikno Mertokusumo, Op.cit., hlm. 4.

10 J.A.Pontier, Rechtsvinding, Cetakan ke-3, Ars Aequi Libri, Nijmegen, 1995, diterjemahkan oleh B. Arief Sidharta, Laboratorium Hukum Fakultas Hukum Universitas Katolik Parahyangan, Bandung, 2001, hlm. 1.

11 Dalam era reformasi berkenaan dengan pelembagaan fungsi peradilan banyak dibentuk lembaga peradilan khusus, dilain pihak pada tiap-tiap sektor pemerintah terus berkembang keinginan untuk membentuk lembagaperadilan peradilan baru, Ibid. 
Memasuki awal abad 21, gelombang reformasi yang terus berkembang tidak saja mendesak bidang ekonomi tetapi melanda dengan kuatnya memasuki bidang hukum dan lembaga peradilan. Sebagai dampaknya, wacana memunculkan lembagalembaga penyelesaian sengketa baru dengan melembagakan secara khusus fungsi-fungsi tertentu yang dalam pengadilan khusus yang sebelumnya belum pernah ada menjadi sangat kuat. Seperti pengadilan niaga, pengadilan HAM, pengadilan Tipikor dimana ada 11 jenis pengadilan khusus dalam sistem peradilan di Indonesia.

Pembentukan pengadilan khusus telah diatur dalam Pasal 27 ayat (1) UU Nomor 48 Tahun 2009 bahwa:

"Pengadilan khusus hanya dapat dibentuk dalam salah satu lingkungan peradilan yang berada di bawah Mahkamah Agung sebagaimana dimaksud dalam Pasal 25"

Diatur lebih tegas lagi pada Pasal 38 Bab $\mathrm{V}$ berjudul Badan-badan Lain Yang Fungsinya Berkaitan dengan Kekuasaan Kehakiman, dijelaskan bahwa:

"Selain Mahkamah Agung dan badan peradilan di bawahnya serta Mahkamah Konstitusi, terdapat badan-badan lain yang fungsinya berkaitan dengan kekuasan kehakiman".
Pada ayat (2) diatur tentang fungsi yang berkaitan dengan kekuasaan kehakiman sebagaimana dimaksud pada ayat (1) meliputi: a. penyelidikan dan penyidikan;

b. penuntutan;

c. pelaksanaan putusan;

d. pemberian jasa hukum; dan

e. penyelesaian sengketa di luar pengadilan.

Selanjutnya diakhiri dengan penegasan bahwa ketentuan mengenai badan-badan lain yang fungsinya berkaitan dengan kekuasaan kehakiman diatur dalam undang-undang.

Kekhususan pengadilan ini dapat diidentifikasi dalam beberapa aspek, yaitu:

a. berdasarkan subyek hukumnya;

b. berdasarkan substansi hukumnya;

c. berdasarkan faktor kesejarahan dan budaya, seperti lahirnya Mahkamah Syariah di NAD ${ }^{12}$

Menelaah ketentuan yang terkait dengan pembentukan pengadilan khusus tersebut, maka undang-undang yang dimaksud adalah undang-undang yang terkait dengan pembentukan bidang khusus tersebut. Berkembangnya gagasan untuk membentuk badan-badan yang fungsinya berkaitan dengan kekuasaan kehakiman yang berbentuk komisikomisi independen, tidak dapat dilepaskan dengan perkembangan yang terjadi di negara lain. Di Amerika Serikat, sejak pertengahan abad ke-20, banyak sekali komisi-komisi independen yang dibentuk dengan fungsi 
yang bersifat campuran antara fungsi regulasi, administrasi, dan juga semi-judisial. ${ }^{13}$ Salah satu komisi independen yang bersifat quasi yudisiil yang dibentuk pemerintah Indonesia adalah KPPU.

Undang-undang Nomor 5 Tahun 1999 sama sekali tidak menyebut KPPU sebagai lembaga peradilan, sehingga jika KPPU dipertanyakan kedudukannya sebagai lembaga yang mengemban fungsi mengadili, hal itu wajar untuk dipertanyakan. Meskipun demikian, KPPU dalam kerangka teoritis pada hakikatnya merupakan lembaga semi-yudisial atau quasi-yudisiil. Beberapa ketentuan yang menegaskan kedudukannya sebagai lembaga peradilan quasi yudisiil dalam arti luas, hal ini dapat dilihat dalam kaitannya dengan tugas dan kewenangannya untuk (i) memeriksa, (ii) memberikan penilaian, (iii) memutuskan dan menetapkan kerugian, dan (iv) memberikan sanksi berupakan tindakan administrasi (administrative treatment) dalam proses pembuktian kasus-kasus dugaan pelanggaran larangan monopoli dan persaingan usaha tidak sehat. Pasal 35 (a), (b), (c), dan (d) serta Pasal 36 (c), (d), (e), (f), dan (h) UU Persaingan Usaha.

Pasal 35 menentukan bahwa KPPU, (a) melakukan penilaian terhadap perjanjian yang dapat mengakibatkan terjadinya praktik monopoli dan atau persaingan usaha tidak sehat sebagaimana diatur dalam Pasal 4 sampai dengan Pasal 16; (b) melakukan penilaian terhadap kegiatan usaha dan atau tindakan pelaku usaha yang dapat mengakibatkan terjadinya praktik monopoli dan atau persaingan usaha tidak sehat sebagaimana diatur dalam Pasal 17 sampai dengan Pasal 24; (c) melakukan penilaian terhadap ada atau tidak adanya penyalahgunaan posisi dominan yang dapat mengakibatkan terjadinya praktik monopoli dan atau persaingan usaha tidak sehat sebagaimana diatur dalam Pasal 25 sampai dengan Pasal 28; dan (d) mengambil tindakan sesuai dengan wewenang Komisi sebagaimana diatur dalam Pasal 36.

Pasal 36 menentukan "Melakukan ... pemeriksaan terhadap kasus dugaan praktik monopoli dan atau persaingan usaha tidak sehat ... atau menghadirkan pelaku usaha, saksi, saksi ahli, atau setiap orang sebagaimana dimaksud huruf e dan huruf f, yang tidak bersedia memenuhi panggilan Komisi"; (d) "Meminta keterangan dari instansi Pemerintah dalam kaitannya dengan ... pemeriksaan terhadap pelaku usaha yang melanggar undang-undang ini”; (e) “... menilai surat, dokumen, atau alat bukti lain guna ... pemeriksaan"; (f) Memutuskan dan menetapkan ada atau tidak adanya kerugian di pihak pelaku usaha lain atau masyafakat"; dan (h) "Menjatuhkan sanksi berupa tindakan administrative kepala pelaku usaha yang melanggar ketentuan undang-undang ini”.

Dalam pemeriksaan, KPPU menilai alat-alat bukti yang menurut Pasal 42 UU Persaingan Usaha terdiri atas (i) keterangan saksi, (ii) keterangan ahli, (iii) surat atau 
dokumen, (iv) petunjuk, dan (v) keterangan pelaku usaha. Proses pembuktian dalam pemeriksaan tidak ubahnya seperti pembuktian dalam proses peradilan pada umumnya. Dari tugas dan wewenang KPPU seperti tersebut di atas, jelas bahwa pada hakikatnya KPPU adalah lembaga peradilan dalam arti yang luas. Oleh karena KPPU merupakan lembaga yang menjalankan fungsi semi-peradilan atau quasi-yudisiil, maka tentu para anggota KPPU atau para komisioner mempunyai kedudukan juga sebagai semi-hakim atau quasi-yuris. Dengan demikian, para komisioner KPPU haruslah bertindak sesuai dengan prinsipprinsip umum (universal) yang berlaku bagi para hakim. Menurut Bagir Manan, hakim dalam menyelesaikan suatu perkara harus mengadili dengan beberapa tolok ukur berikut:

1. Setiap putusan hakim harus mempunyai dasar hukum substantif dan prosedural yang telah ada sebelum perbuatan melawan hukum atau pelanggaran terjadi;

2. hakim dalam mengadili menurut hukum harus diartikan luas melebihi pengertian hukum tertulis dan tak tertulis. Hukum dalam kasus atau keadaan tertentu meliputi pengertian yang mengikat pihak-pihak, kesusilaan yang baik, dan ketertiban umum (goede zeden en openbaar orde);

3. Hukum yang hidup dalam masyarakat adalah hukum yang dipertimbangkan dalam putusan hakim, tetapi tidak selalu harus diikuti, karena kemungkinan the living law, justru harus dikesampingkan karena tidak sesuai dengan tuntutan sosial baru;

4. hakim wajib mengutamakan penerapan hukum tertulis, kecuali kalau akan menimbulkan ketidakadilan, bertentangan dengan kesusilaan atau ketertiban umum. ${ }^{14}$

Di dalam Judicial Conduct itu disepakati adanya prinsip-prinsip yang harus dijadikan pegangan oleh setiap hakim di seluruh dunia, yaitu prinsip-prinsip (i) independence (kemandirian), (ii) impartiality (netralitas atau ketidakberpihakan), (iii) integrity (keutuhan dan keseimbangan kepribadian), (iv) propriety (kepantasan dan kesopanansantunan), (v) equality (kesetaraan), (vi) competence (kecakapan), dan (vii) diligence (keseksamaan). Prinsip-prinsip perilaku yang diidealkan bagi setiap hakim tersebut, tentu harus tercermin pula dalam perilaku setiap komisioner KPPU, baik bagi ketua, wakil ketua, dan para anggota KPPU tidak boleh melanggar dan haruslah berusaha untuk mencegah dirinya masing-masing secara sengaja atau tidak sengaja dari sikap melanggar ketujuh prinsip perilaku ideal tersebut.

\section{B. Metode Penemuan Hukum oleh KPPU}

Pandangan klasik dari Montesquieu dan Immanuel Kant yang menyatakan bahwa, hakim menjadi corong dari undang-undang, 
dia tidak dapat mengubah atau menambah undang-undang, ${ }^{15}$ pandangan itu didasarkan pada pemikiran bahwa, demi kepastian hukum dan untuk melindungi warga masyarakat dari tindakan sewenang-wenang hakim, maka hakim harus tunduk pada undang-undang. Saat ini pandangan tersebut sudah tidak dapat dipertahankan lagi, pandangan yang berkembang bahwa hakim harus mandiri, otonom, inisiatif dan aktif sudah diterima seperti oleh Van Eikema Hommes yang kemudian dipertahankan oleh Oskar Bullow dan Eugen Erlich (Jerman) dan Francois Geny (Perancis) serta Oliver Wendel Holmes dan Jerome Frank (Amerika). Menurut pandangan ini undang-undang itu belum lengkap, dan tidak mungkin lengkap, maka hakim harusnya melengkapi undang-undang itu ketika menerapkan pada peristiwa-peristiwa konkrit dengan melakukan penemuan hukum.

Penemuan hukum merupakan sebuah reaksi terhadap situasi-situasi problematikal yang berkenaan dengan pertanyaanpertanyaan hukum (rechtsvragen), konflikkonflik hukum atau sengketa-sengketa konkret. Penemuan hukum itu terkait dengan tafsiran, penerapan aturan hukum, pertanyaan tentang makna dari fakta dimana hukum harus diterapkan berkenaan dengan hal menemukan penyelesaian-penyelesaian dan jawabanjawaban berdasarkan kaidah hukum. ${ }^{16}$

Metode penemuan hukum oleh hakim dikenal ada beberapa cara, yaitu:

1. Metode interpretasi menurut bahasa (gramatikal) yaitu suatu cara penafsiran Undang-undang menurut arti kata-kata (istilah) yang terdapat pada undangundang;

2. Metode interpretasi secara sistematis yaitu penafsiran yang menghubungkan pasal yang satu dengan pasal yang lain dalam suatu undang-undang yang bersangkutan, atau dengan undang-undang lain, serta membaca penjelasan undang-undang tersebut untuk memahami maksudnya;

3. Metode Teleologis Sosiologis yaitu makna undang-undang itu ditetapkan berdasarkan tujuan kemasyarakatan artinya peraturan perundang-undangan disesuaikan dengan hubungan dan situasi sosial yang baru. Ketentuan undang-undang yang sudah tidak sesuai lagi disesuaikan dengan keadaan sekarang;

4. Metode Ekstentif yaitu penafsiran dengan cara memperluas arti kata-kata yang terdapat dalam undang-undang sehingga suatu peristiwa dapat dimasukkan kedalamnya;

5. Metode Restriktif yaitu penafsiran yang membatasi/mempersempit maksud suatu pasal dalam undang-undang seperti: Putusan Hoge Raad Belanda tentang kasus Per Kereta Api "Linden baum" bahwa kerugian yang dimaksud pasal 
1365 KUHPerdata juga termasuk kerugian immateril yaitu pejalan kaki harus bersikap hati-hati sehingga pejalan kaki juga;

6. Metode Analogi yaitu memberi penafsiran pada sesuatu peraturan hukum dengan menyamakan azas hukumnya sehingga suatu peristiwa yang sebenarnya tidak termasuk kedalamnya dianggap sesuai dengan bunyi peraturan tersebut;

7. Metode Argumentus a contrario yaitu suatu penafsiran yang memberikan perlawanan pengertian antara peristiwa konkrit yang dihadapi dengan peristiwa yang diatur dalam undang-undang.

Ketentuan undang-undang tidak dapat diterapkan begitu saja secara langsung pada peristiwa konkrit, sehingga untuk dapat menerapkan ketentuan undang-undang yang bersifat umum dan abstrak pada peristiwa yang konkrit dan khusus sifatnya, ketentuan undang-undang itu harus diberi arti terlebih dahulu, dijelaskan atau ditafsirkan dan diarahkan atau disesuaikan dengan peristiwanya untuk kemudian baru diterapkan pada peristiwanya. Peristiwa hukumnya harus dicari lebih dahulu yang manakah peristiwa konkrit yang terjadi itu, kemudian undangundangnya ditafsirkan untuk dapat diterapkan pada peristiwa tersebut

Dalam bidang hukum persaingan usaha, perbuatan yang dilakukan oleh pelaku usaha yang dilarang dalam hukum persaingan usaha merupakan suatu peristiwa konkrit yang harus dapat ditentukan oleh KPPU. Untuk menentukan perbuatan tersebut apakah termasuk perbuatan yang dilarang atau bukan, maka KPPU harus mengkaji dengan seksama apa yang dilakukan oleh pelaku usaha. Selanjutnya dicari dalam ketentuan hukum (UU Persaingan Usaha) pada pasal mana perbuatan tersebut dapat diterapkan. Metode penemuan hukum (dicari dulu dalam pasal-pasal) UU Persaingan Usaha didasarkan pada suatu metode. Metode pendekatan yang dimaksud dikenal dengan nama per se illegal dan rule of reason. Kedua Pendekatan itu digunakan untuk menafsirkan apakah tindakan pelaku usaha itu (baik berupa perjanjian atau kegiatan) benar-benar telah melanggar hukum persaingan usaha atau tidak. Melalui penafsiran secara per se illegal atau rule of reason akan ditentukan ada atau tidaknya pelanggaran itu.

Kalau kita cari penyebutan kata per se illegal dan rule of reason dalam pasal-pasal UU Persaingan Usaha tidak akan kita temukan, tetapi berbagai literatur mengungkapkan bahwa pasal-pasal dalam UU Persaingan Usaha merupakan ketentuan yang bersifat se illegal dan rule of reason. ${ }^{17}$ Bahkan KPPU sendiri menggunakan metode pendekatan se illegal dan rule of reason ketika menafsirkan bentuk-bentuk perjanjian dan kegiatan yang dilarang dilakukan oleh pelaku usaha. ${ }^{18}$ Untuk 
memahami asal mula keberadaan metode per se illegal dan rule of reason tidak boleh mengabaikan doktrin-doktrin hukum yang dikembangkan dalam tradisi hukum Antitrust.

Sherman Act sebetulnya juga tidak menyebutkan istilah per se illegal dan rule of reason, tetapi kedua prinsip itu dikembangkan dalam fakta hukum oleh hakim Federal Trade Commission (FTC) saat menafsirkan perbuatan-perbuatan pelaku usaha yang dinilai menghambat atau membatasi perdagangan. Dengan demikian, sejarah penerapan kedua pendekatan tersebut muncul dari interpretasi hakim yang kemudian menjadi pertimbangan hakim dalam putusannya. Oleh sebab itu, metode pendekatan per se illegal dan rule of reason merupakan metode penafsiran yang digunakan oleh KPPU. Pendekatan per se illegal dan rule of reason dapat dilakukan dengan dua cara, yaitu: (a) melihat ketentuan yang terdapat dalam UU Nomor 5 Tahun 1999 dan (b) menganalisis keputusan KPPU. ${ }^{19}$

Di dalam kepustakaan hukum, kata $\mathrm{Per}$ se berasal dari bahasa Latin, namun dalam bahasa Inggris disebut sebagai by it self; in itself; taken alone; by means of it self; through itself; inherenly; in isolation; unconnected with other matter; simply as such atau in its own nature without reference to its relation. ${ }^{20}$ Istilah per se illegal seringkali digunakan secara identik dengan istilah per se doctrine, per se rule, dan per se violation. Per se illegal adalah suatu perbuatan yang secara inheren bersifat dilarang atau illegal tanpa perlu pembuktian terhadap dampak dari perbuatan tersebut. Sehingga terminologi ini berkenaan dengan keadaan yang tidak memerlukan bukti yang tidak berhubungan (extraneous evidence) atau pendukung atas suatu kejadian. ${ }^{21}$

Didefinisikan oleh Asril Sitompul, per se rule adalah suatu pendekatan dimana perbuatan dinyatakan sebagai pelanggaran dan dapat dihukum tanpa perlu melakukan pertimbangan apakah perbuatan tersebut mengakibatkan kerugian atau menghambat persaingan. ${ }^{22}$ Sejalan dengan pendapat Yahya Harahap, arti per seillegal adalah “sejak semula tidak sah", dengan sendirinya perbuatan itu merupakan perbuatan yang “melanggar hukum". ${ }^{23}$ Penerapannya di dalam

18 Putusan KPPU Nomor 03/KPPU-1/2003, Perbuatan yang diindikasikan sebagai pelanggran per se illegal adalah perjanjian secara bersama-sama oleh 7 (tujuh) pelaku usaha di bidang transportasi laut yang berisi pengaturan tarif dan kuota yang melayani jalur pelayaran Surabaya-Makasar-Surabaya dan jalur Makasar - Jakarta Makasar. Dari hasil pemeriksaan KPPU diperoleh bukti yang kuat bahwa 7 (tujuh) pelaku usaha bidang angkutan laut itu (Terlapor I sampai Terlapor VII) secara sah dan meyakinkan telah melakukan pelanggaran terhadap Pasal 5 ayat (1) yaitu melakukan perjanjian penetapan harga yang mengakibatkan terjadinya persaingan usaha tidak sehat serta melanggar ketentuan Pasal 19 huruf (a) UU Persaingan Usaha.

19 Yakub Adi Krisanto, Prinsip Rule of Reason dan Perse Illegal, http:/yakubadikrisanto.wordpress. com/2008/06/03/prinsip-rule-of-reason-dan-per-se-illegal/, diakse 21 Juni 2009, pukul 12.15 WIB.

20 Johnny Ibrahim, Hukum Persaingan Usaha, Filosofi, Teori, dan Implikasi Penerapannya di Indonesia, Bayumedia, Malang, 2007, hlm. 222.

21 Sutrisno Iwantono, Perse Illegal dan Rule of Reason dalam Hukum Persaingan Usaha, http://www.ocw. usu.ac.id, diakses 20 April 2009, PUKUL 12.30 wib, hlm.1.

22 Asril Sitompul, Praktek Monopoli dan Persaingan Usaha Tidak Sehat (Tinjauan Terhadap Undangundang Nomor 5 Tahun 1999), Citra Aditya bakti, Bandung, 1999, hlm. 24. 
undang-undang, jika perbuatan tersebut telah memenuhi rumusan dalam undang-undang tidak diperlukan lagi pembuktian terhadap pelanggaran yang dilakukan, pelaku usaha itu dikatakan telah melanggar hukum, itulah yang disebut sebagai per se illegal.

Sedangkan Pendekatan rule of reason adalah suatu pendekatan yang digunakan oleh KPPU untuk membuktikan perilaku (conduct) pelaku usaha dengan membuat evaluasi mengenai akibat perjanjian atau kegiatan usaha tertentu, guna menentukan apakah suatu perjanjian atau kegiatan tersebut bersifat menghambat atau mendukung persaingan. Pendekatan ini memungkinkan pengadilan melakukan interpretasi terhadap bunyi pasal dalam UU Persaingan Usaha. Pada pasal-pasal rule of reason lazimnya terdapat anak kalimat atau diakhiri dengan kalimat “......yang mengakibatkan praktek monopoli dan persaingan usaha tidak sehat"; "patut diduga" atau "dianggap". Oleh karenanya, pendekatan ini digunakan sebagai penyaring untuk menentukan apakah perilaku pelaku usaha menimbulkan praktek monopoli atau persaingan usaha yang tidak sehat atau tidak.

Permasalahan dalam hukum persaingan tidak lagi semata-mata persoalan persaingan pasar akan tetapi lebih kepada masalah perilaku (conduct). ${ }^{24}$ Tidak ada larangan terhadap persaingan pasar monopoli, oligopoli atau posisi dominan, namun menjadi dilarang jika terdapat perilaku yang merugikan (injuries conduct). Doktrin rule of reason merupakan doktrin yang hidup dalam tradisi hukum common law (case law). Salah satu perkara yang cukup dikenal dalam hukum persaingan dan merupakan perkara yang lahir dari putusan berdasarkan pendekatan rule of reason adalah kasus Mitchel V. Reynolds. ${ }^{25}$ Kasus ini memberikan gambaran tentang perjanjian perdagangan (sale agreement) yang bersifat anti persaingan (non competation) yang seharusnya dilarang, namun oleh hakim yang menangani perkara tetap dinyatakan berlaku. Perjanjian tersebut dianggap layak dan patut meskipun masyarakat tidak juga memperoleh produk yang kompetitif karena tiadanya persaingan dalam pasar yang sudah dikuasai oleh penjual yang mengadakan perjanjian dagang.

Hakim memutuskan bahwa tidak semua perjanjian yang menghalangi perdagangan adalah melanggar hukum, tetapi hanya perjanjian yang tidak masuk akal (unreasonable ones) yang dinilai melanggar hukum. Dasar pertimbangan hakim tidak melarang perjanjian tersebut, karena manfaat jangka panjang untuk memberikan insentif bagi pengembangan perusahaan sejenis dikemudian hari akan melebihi kerugian yang bersifat terbatas dan sementara terhadap

23 M Yahya Harahap, Beberapa Tinjauan tentang Permasalahan Hukum (II), Citra Aditya Bakti, Bandung, 1997, hlm. 28.

24 Sutrisno Iwantono, Op.cit., hlm. 2.

25 Stephen F.Ross, Principle of Antitrust Law, The Foundation Press, Inc, Westbury, New York, 1993, hlm. 14. 
persaingan. Jadi Rule of reason ukurannya terdapat pada reasonableness. Kriteria reasonableness dalam menentukan perbuatan yang melanggar hukum persaingan adalah: ${ }^{26}$

a. Akibat yang ditimbulkan dalam pasar dan persaingan;

b. Pertimbangan bisnis yang mendasari tindakan tersebut;

c. Kekuatan pangsa pasar (market power);

d. Alternatif yang tersedia;

e. Tujuan dari tindakan tersebut

Wilayah rule of reason memiliki ruang yang cukup luas untuk diinterpretasikan oleh setiap orang. Pandangan hakim, KPPU, auditor, pelaku usaha, ekonom, atau akademisi sangat diharapkan memiliki kesepahaman dalam menafsirkan pasal-pasal rule of reason. Oleh sebab itu pasal-pasal yang bersifat rule of reason hendaknya memiliki penjelasan yang cukup bisa dimengerti dan implemantatif. Dengan demikian laranganlarangan yang bersifat rule of reason harus dirumuskan dengan makna lebih tersurat dan implementatif agar pelaku usaha tidak takut dibayang-bayangi pasal-pasal yang dengan tanpa dimengerti akan menjerat kegiatan usahanya.

\section{Simpulan}

Penemuan hukum merupakan proses pembentukan hukum oleh hakim atau aparat penegak hukum lainnya dalam rangka untuk menerapkan peraturan hukum umum pada peristiwa hukum konkret. Aparat penegak hukum lain selain hakim yang fungsinya berkaitan dengan kekuasaan kehakiman seperti halnya KPPU, telah diatur dalam Bab V Undang-undang Nomor 48 Tahun 2009 tentang Pengaturan Badan-badan Lain Yang Fungsinya Berkaitan dengan Kekuasaan Kehakiman. Ketentuan tersebut semakin menegaskan fungsi KPPU sebagai lembaga semi-peradilan khusus bidang persaingan usaha.

KPPU dapat melakukan penemuan hukum karena KPPU adalah komisi yang berwenang memutus perkara bidang persaingan usaha. Putusan KPPU didasarkan pada interpretasi hakim (komisoner) melalui pendekatan per se illegal atau rule of reason. Per se illegal merupakan interpretasi dengan melihat rumusan undang-undang saja, tanpa melihat akibat yang ditimbulkan dari perbuatan pelaku usaha, sedangkan rule of reason harus melakukan interpretasi terhadap bunyi pasal dalam UU persaingan Usaha, yaitu dengan mengevaluasi akibat yang ditimbulkan terhadap pasar akan adanya persaingan usaha tidak sehat dan merugikan masyarakat. 


\section{DAFTAR PUSTAKA}

\section{Buku}

Asril Sitompul, 1999, Praktek Monopoli dan Persaingan Usaha Tidak Sehat (Tinjauan Terhadap Undang-undang Nomor 5 Tahun 1999), Citra Aditya Bakti, Bandung.

Bagir Manan, 2009, Menegakkan Hukum Suatu Pencarian, Asosiasi Advokad Indonesia, Jakarta.

J.A.Pontier, 1995, Rechtsvinding, Cetakan ke-3, Ars Aequi Libri, Nijmegen, diterjemahkan oleh B. Arief Sidharta, 2001, Laboratorium Hukum Fakultas Hukum Universitas Katolik Parahyangan, Bandung.

Jimly Assiddiqie, 2010, Perkembangan dan Konsolidasi Lembaga Negara Pasca Reformasi, Sinar Grafika, Jakarta.

Johnny Ibrahim, 2007, Hukum Persaingan

Usaha, Filosofi, Teori, dan Implikasi Penerapannya di Indonesia, Bayumedia, Malang.

L. Budi Kagramanto, 2008, Mengenal Hukum Persaingan Usaha (Berdasarkan UU No. 5 Tahun 1999), Laros, Surabaya. M Yahya Harahap, 1997, Beberapa Tinjauan

Tentang Permasalahan Hukum (II), Citra Aditya Bakti, Bandung.

Michael Sandel, 2004, Justice: Whats The Right Thing To Do?, Farrar, Straus And Giroux, New York.
Ningrum Natasya Sirait, 2004, Hukum Persaingan Usaha, UU No5/1999 tentang Larangan Praktek Monopoli dan Persaingan Usaha Tidak Sehat, Pustaka Bangsa.

Stephen F.Ross, 1993, Principle of Antitrust Law, The Foundation Press, Inc, Westbury, New York.

Sudikno Mertokusumo dan Pitlo, 1993, Bab-bab tentang Penemuan Hukum, Citra Aditya Bakti, Bandung.

Yudha Bakti Adhiwisastra, 2000, Penafsiran dan Konstruksi Hukum, Alumni, Bandung.

\section{Jurnal}

Bagir Manan, 2007, Menjadi Hakim yang Baik, Varia Peradilan, No. 255, Februari.

Stefino Anggaram, 2009, Komisi Pengawas Persaingan Usaha (Kedudukan KPPU dalam UU Nomor 4 Tahun 2004), Jurnal Persaingan Usaha, Edisi I.

\section{Makalah}

Peter Mahmud Marzuki, 2012, Penemuan Hukum, Makalah Seminar Nasional Peran Hakim dalam Penemuan Hukum tanggal 22 September 2012, Fakultas Hukum Universitas Airlangga, Surabaya. 
Naskah Internet

Jimly Assiddiqie, Fungsi Campuran KPPU

Sebagai Quasi Peradilan, http://www. jimly.com/makalah/namafile/61/ Makalah_KPPU_Koreksian.pdf, Sutrisno Iwantoro, Perse Illegal dan Rule of Reason dalam Hukum Persaingan

Usaha, http://www.ocw.usu.ac.id.
Yakub Adi Krisanto, Prinsip Rule of Reason dan Per se illegal, http:// yakubadikrisanto.wordpress. com/2008/06/03/prinsip-rule-ofreason-dan-per-se-illegal/, diakses 21 Juni 2009 